\title{
Misconceptions about the Settlement of the Americas: Interview with Kenneth L. Feder
}

\author{
Glenn Branch • W. Eric Meikle
}

Published online: 21 May 2011

(C) Springer Science+Business Media, LLC 2011

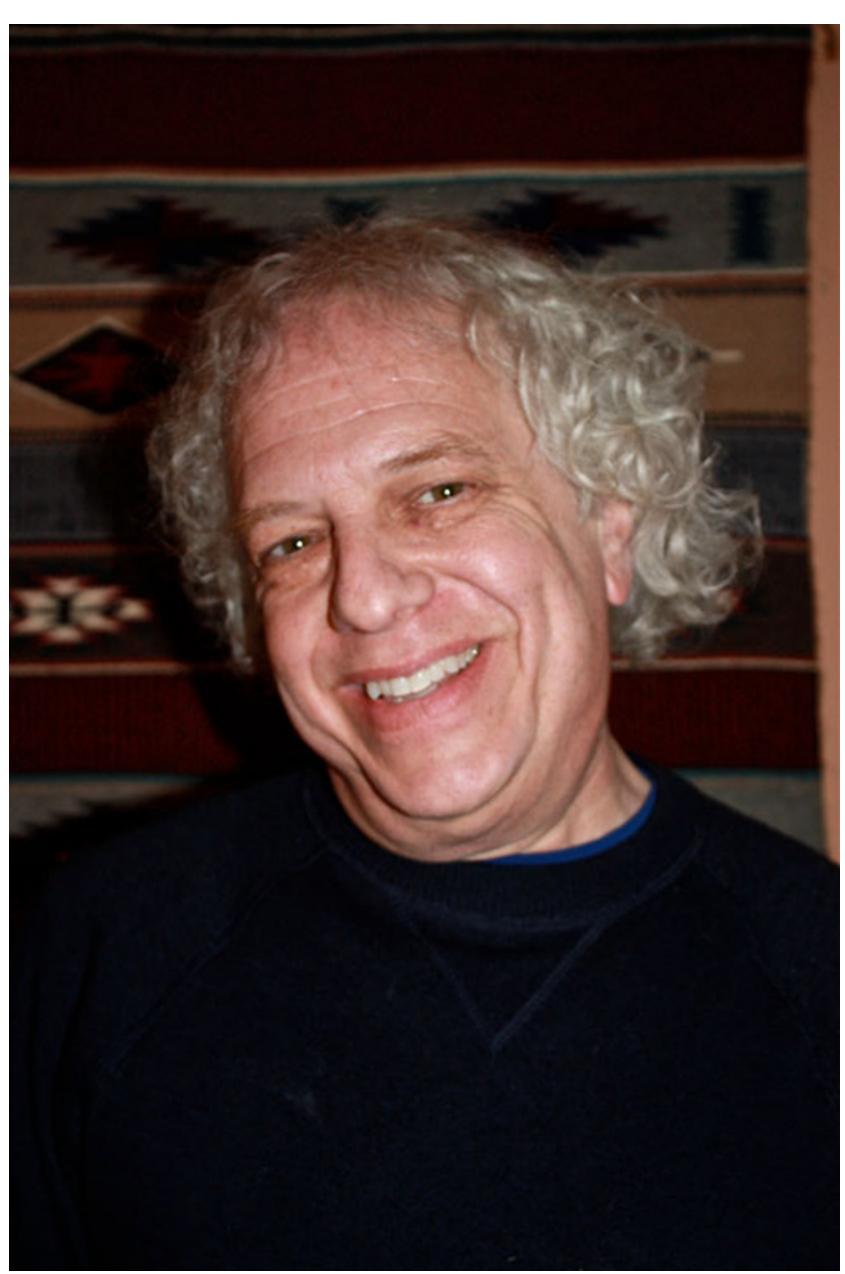

Kenneth L. Feder

Interview conducted by Glenn Branch and W. Eric Meikle

G. Branch $(\bowtie) \cdot$ W. E. Meikle

National Center for Science Education,

PO Box 9477, Berkeley, CA 94709-0477, USA

e-mail: branch@ncse.com
Abstract Kenneth L. Feder, a specialist in archaeological pseudoscience, addresses prevalent misconceptions about the settlement of the Americas, discussing how they are stimulated by ethnic pride and religious faith, propagated uncritically in the media, and accepted by students. Sources of information on such misconceptions and strategies for helping students to overcome them are briefly sketched.

Keywords Kenneth L. Feder - Settlement of the Americas . Archaeology $\cdot$ Pseudoscience

NCSE's regular column for Evolution: Education and Outreach is dedicated, as its title declares, to overcoming obstacles to evolution education. In the case of teaching about the settlement of the Americas, not all of the obstacles are about evolution, strictly speaking. Yet it would be surprising if there were no similarities, since in both cases, misconceptions about the prehistoric past and about how scientists investigate it are a major source of the obstacles.

To help to identify and suggest remedies for misconceptions about the settlement of the Americas, we have asked Kenneth L. Feder, Professor of Anthropology at Central Connecticut State University, to answer ten questions. A specialist in archaeological pseudoscience, Feder is the author of the standard textbook on the subject, Frauds, Myths, and Mysteries: Science and Pseudoscience in Archaeology, now in its seventh edition (Feder 2011), as well as a new encyclopedia of "dubious archaeology" (Feder 2010).

Let's begin with what may be the most common misconception about the settlement of the Americas: Did Columbus discover America?

Back in 1992, a group of Latin American representatives to the United Nations proposed a ceremonial resolution 
to honor the 500th anniversary of the "discovery" of America by Christopher Columbus. In response, the representative from Iceland complained that a Norseman, Leif Ericson, was the true discoverer of the Americas, about 500 years before Columbus. The Irish ambassador objected further, claiming that not Columbus or Ericson but an Irish monk, St. Brendan, had actually discovered the New World in the sixth century, 500 years before the Norseman and close to 1,000 years before Columbus's voyages.

In truth, these ambassadors were off by more than ten millennia and wrong by any ordinary definition of the term "discover." The first people to discover, explore, and settle the New World were natives of northeast Asia who crossed through the interior or who sailed along the southern coast of the Bering Land Bridge at least 13,000 and as much as 30,000 years ago. The land bridge was a 1,000-mile-wide expanse connecting northeast Asia and northwest North America, exposed between about 35,000 and 10,000 years ago, during the later part of the Pleistocene or "Ice Age." At this time, a large volume of the world's ocean water was bound up on land as glacial ice. (You can see an incredibly cool animation of the Bering Land Bridge at http://instaar.colorado. edu/QGISL/bering_land_bridge/.)

The convergence of archaeological, geological, and genetic evidence is absolutely clear about this. The first human beings to settle in the New World arrived here from Asia sometime after 30,000 years ago. They were the true human discoverers of America.

\section{That's the scientific consensus, of course, but aren't there Native Americans who reject it in favor of their interpretation of their traditional origins stories?}

That's true. There are Native Americans who do not accept the scientific consensus concerning the origins of the human populations of the New World. Vine Deloria (1995), for example, was a vociferous advocate for a literal interpretation of Native American origin stories, many of which posit an in-place creation of the native people of North America. Deloria was a brilliant writer and a tireless worker for Native American causes. He also was, essentially, a creationist. His creationism was not that of fundamentalist Christianity but was informed by a modern, pan-Indian religion. The fact that the creation stories of Native Americans vary widely from tribe to tribe seemed not to trouble Deloria, who maintained that even conflicting stories about creation could all somehow simultaneously be true.

Assertions that the native people of the New World didn't come from anywhere else but were created and placed here is a creationist, religious doctrine. It certainly warrants respect as a faith-based perspective, but it is not informed by scientific evidence or reasoning.

Part of the appeal of such Native American creationism seems to be due to its appeal to ethnic pride: You comment that a Native American told you that his objection to the land bridge scenario was, "It makes us immigrants, no different from you and your ancestors." Are there parallel misconceptions for people from different ethnic backgrounds?

For whatever reason, a number of ethnic groups take it as a point of pride that, in their view, a member of their group discovered America or, at least, was the first nonnortheast Asian to arrive on our shores. At noted above, individuals of Irish and Scandinavian descent have claimed bragging rights to the "discovery" of America. I have met and read a number of articles by an extraordinarily sincere American Jewish woman who has spent much of her adult life trying to support the long-ago disproved claim that American Indians were members of one or more of the so-called Lost Tribes of Israel. The Daughters of the American Revolution, many of whom are of British descent, erected a plaque in Mobile Bay, in Alabama, wherein the supposed discovery of America by the Welsh Prince Madoc in AD 1170 is memorialized. The late Ivan Van Sertima, a professor of African Studies at Rutgers University, was a promulgator and supporter of the claim that West African travelers visited the New World and, essentially, brought civilization to the Indians, igniting the Olmec culture's rise to dominance in lowland Central America (see, e.g., Van Sertima 1976).

Ethnic pride can be a powerful motivation for belief and has been the source of archaeological mischief for decades. Much of the British support for the fraudulent Piltdown Man fossil resulted from the fact that it appeared to give the people of Great Britain something both scientists and the general public there desperately craved - an ancient evolutionary ancestor to rival those found in France and Germany.

The most egregious example of the use of ethnic pride in the support of historical claims that are not supported by archaeological data can be traced to the Nazis (Arnold 1992). Ancient archaeological sites were interpreted by the Nazis as proving the more widespread presence of Aryans in the distant past. In discussing archaeologists and historians, Hitler's Minister of the Interior Heinrich Himmler (who also oversaw the concentration camps) wrote:

The one and only thing that matters to us, and the thing these people are paid for by the State, is to 
have ideas of history that strengthen our people in their necessary national pride. In all this troublesome business we are only interested in one thing - to project into the dim past the picture of our nation as we envisage it for the future... Our teaching of German origins has depended for centuries on falsification. We are entitled to impose one of our own at any time. (Quoted in Arnold 1992:33)

Himmler is chillingly forthcoming in his admission that the truth matters not at all and that archaeology exists to serve the state. The Nazi example shows, in the most extreme case, what can happen when the motivations of ethnicity supersede science.

\section{Are there prevalent misconceptions about the settlement of the Americas that, like Native American creationism, are rooted in religious beliefs?}

Religious dogma has long played a role in speculations about the source of Native Americans. When it was finally recognized that Columbus had not encountered people living just off the coasts of China and Japan but had come upon, as Amerigo Vespucci first characterized it in 1503, "a new world," many European thinkers felt compelled to explain the presence of people in this new world within a biblical framework. In their view, the native people of the Western Hemisphere must be descendants, ultimately, of Adam and Eve and, more recently, of Noah and those saved on board the Ark. Because all three of Noah's sons had been historically accounted for by European biblical scholars (Japheth was presumed to be the ancestor of Europeans, Shem of Asians, and Ham of Africans), Native Americans must be the progeny of one of those already accounted for geographic populations. European thinkers speculated for centuries about which descendants of one or more of Noah's sons had migratedperhaps by boat since, after all, Noah had been a sailor - to the Americas. Furthermore, some members of the Church of Jesus Christ of Latter Day Saints interpret the Book of Mormon as claiming that at least some of the people living in the New World upon Columbus's visits had arrived from Israel around 2,000 years ago. All such speculations are fueled by an attempt to reconcile history with a religious tract's teachings. None is based on an objective analysis of the archaeological record.

\section{Where do students acquire misconceptions such as these?}

From the feedback I receive from students in my classrooms, cable television is a major promulgator of misconceptions about the human past, usually in the guise of scientifically or historically based documentaries. Many of these documentaries are predicated on the assumptions that prehistory and history are rife with unexplained mysteries and, more importantly, that these mysteries cannot be solved by applying the standard scientific approach. From Maya end-time predictions, to ancient alien pyramid builders, to Nostradamus, to an Atlantean super-culture, such documentaries grab the attention of television viewers by claiming, essentially, that those boring scientists in their ivory towers don't have a particularly good idea of - or not a particularly interesting explanation for-what happened in the past and when. Alternative views - often a euphemism for views without any scientific evidence to recommend them-are presented as simply more interesting. Whether they're correct or not seems not to be a primary concern. It's little more than "infotainment," and unfortunately students often don't get the difference between such nonsense and the findings of real science.

\section{Have any of these misconceptions significantly increased or decreased in popularity since you have been studying them? Why?}

I have been informally tracking changes in the popularity of various claims made in the name of archaeology for about 25 years. Essentially, I've asked students on the first day of each semester to complete a survey concerning their level of agreement with a number of statements (about Atlantis, ancient astronauts, King Tut's curse, and some others). The interesting thing I've found is that, yes, the popularity of such things varies from year to year, but no, there isn't an overarching pattern of increasing or decreasing agreement on any specific claim. In essence, dealing with archaeological pseudoscience is an intellectual game of whack-a-mole. A mole pops up its head on one cable channel, archaeologists smack it down, only to have another mole pop up somewhere else, on another channel. I'm sure that this year, one such "mole" will be Maya end-time predictions (which, by the way, the Maya did not make for 2012). This bit of nonsense will fade away once we don't all die on December 21,2012 , only to be replaced by something equally silly.

I can't quite explain why the popularity of various claims waxes and wanes. The Maya end-time prediction is obvious, as the prediction is (supposedly) specific about when the world will end. In other cases, much of it may be media-driven. For example, the ancient astronaut claims have been on the wane for some time; the books of its chief proponent and cheerleader, Erich von 
Däniken (1970, 2000, 2002), don’t sell nearly as well as they once did. A theme park in Switzerland devoted to the ancient astronaut theme (Powell 2004) closed its doors in 2006 as a result of poor attendance (http://www. swissinfo.ch/eng/Home/Archive/Closure_of_Mystery_ Park is no enigma.html?cid=5576928). But a recent cable series devoted to the claim that human antiquity is filled with evidence of the visits of extraterrestrial aliens has been wildly popular during the last couple of years, and I expect to see a corresponding uptick in student interest in and acceptance of that idea.

\section{What misconceptions do you find to be prevalent among your undergraduate students?}

For my money, the most important misconceptions students have are not about specific claims, but about the scientific method itself. They don't understand that the pursuit of knowledge through science is necessarily an imperfect process, characterized by fits and starts, mistakes, blind alleys, and multiple returns to the "drawing board." Too many of our students view all this as meaning that science is no better than any other pathway toward knowledge (intuition, revelation, etc.), because it's a messy process. They seem not to understand that allowing for mistakes and revision is a fundamental strength of the scientific process.

\section{What sources of information would you recommend to teachers, particularly at the high school level, to help them to understand these misconceptions and to prepare for students who may have been exposed to them?}

I would recommend my own book Frauds, Myths, and Mysteries: Science and Pseudoscience in Archaeology (Feder 2011) as a good place for students to start. My latest book, The Encyclopedia of Dubious Archaeology (Feder 2010), is geared specifically to a high school audience. As a one-volume encyclopedia with a series of concise, relatively short, alphabetically organized listings, it's another good place for students to begin their investigation of the scientific approach to claims made about human antiquity.

For books with detailed treatments of pseudoscience in archaeology and anthropology, suitable for high school students, I would also recommend:

- On the Bermuda Triangle, Larry Kusche's The Bermuda Triangle Mystery Solved (1995).

- On Atlantis, there is no better source than Paul Jordan's The Atlantis Syndrome (2001).
- On astronomy, Phil Plait's Bad Astronomy (2002) is fantastic.

- On the Shroud of Turin, there's none better than Joe Nickell's Inquest on the Shroud of Turin (1987).

- On Bigfoot, I think that David J. Daegling's Bigfoot Exposed (2005) is a great read.

- On the chupacabra, Ben Radford's new book Tracking the Chupacabra (2011) puts that story to rest.

For a nice array of websites applying the scientific method in dealing with popular (and often alternative) claims related to the human past, visit the home page of my Frauds book (you don't need a password and you don't have to purchase the book to access the page) for links to a bunch of great sites, organized by the chapters of my book: http://highered.mcgraw-hill.com/sites/ 007811697x/student_view0/index.html. Under each chapter in the pull-down list on the left, select "Best of the Web" for direct links to websites related to the chapter's topic. You can also find a "Video Companion Guide" on the Frauds website with recommendations for videos related to some of those same issues.

How can teachers help their students recognize the differences among "frauds, myths, and mysteries" with regard to the settlement of the Americasthat is, knowing when a claim is a downright hoax, when it is pseudoscientific, and when it is merely taking a stand on a question where there is no settled scientific consensus? How do you motivate them to examine their misconceptions, and what tools are useful for them in doing so?

As in any other field of inquiry, teachers can lay out the basic framework of the scientific method and have students figure out where and how some claims made on websites or television documentaries fall short. Like all of us, students don't like being fooled and, with the proper analytical tools, they often can figure out a scam or a hoax. The "Quick Start Guide" in my Frauds, Myths, and Mysteries (Feder 2011) presents a checklist that students can apply to claims made about the human past - or any other field of inquiry. The Guide suggests that, faced with extraordinary claims or revolutionary interpretations about the human past in the popular media, you ask questions like:

- Where is the particular claim or discovery presented? Is it in a media outlet with the ability (and the willingness) to report accurately on scientific topics?

- Who is making the claim? Is it a scientific researcher trained in archaeology, anthropology, or history? 
- How does the person announcing the discovery, making the claim, or interpreting the results of the study "know"? Is scientific methodology being followed?

- Were the views of other experts presented? Were they in agreement, skeptical, or in disagreement?

- Were any confirming data presented? Is the particular claim or discovery consistent with what is already established about the topic?

- Were enough data presented for you to decide whether the claim or discovery was legitimate, or are there still important questions unaddressed?

Additionally, all of the Best of the Web sites accessible on the Frauds web page are useful.

\section{Why is it important that people understand what we know, and how we know it, about the settlement of the Americas?}

The best answer to such a question is another question: How could it not be important to truly understand a crucial part of the human past: the discovery and populating of two continents? In essence, the exploration of, migration to, settlement of, and adaptation to the many and diverse environments of the New World provides anthropologists, historians, cultural geographers, human ecologists, demographers, etc., with what amounts to a laboratory in which they can study the myriad ways in which people create ways to live. Understanding the timetable for these adaptations, the source populations, and the environmental changes these people faced can help to illuminate the human condition and, if we're lucky, remind us in the present about ancient responses to the sometimes remarkably similar challenges we face today (Sabloff 2008). We in the present are not the first people faced with the challenges of environmental change, population pressure, species extinction, resource depletion, soil erosion, and warfare. A broad and accurate understanding of how people reacted to these and similar challenges can only help us develop responses to those we face in the modern world. We can't base those responses on fables, wishful thinking, speculation, frauds, myths, or mysteries. We need real data and explanations supported through scientific reasoning.

\section{References}

Arnold B. The past as propaganda: how Hitler's archaeologists distorted European prehistory to justify racist and territorial goals. Archaeology. 1992;45:30-7.

Daegling DJ. Bigfoot exposed: an anthropologist examines America's enduring legend. Walnut Creek: AltaMira Press; 2005.

Deloria Jr V. Red earth, white lies: Native Americans and the myth of scientific fact. New York: Scribners; 1995.

Feder KL. The encyclopedia of dubious archaeology: from Atlantis to the Walam Olum. Santa Barbara: Greenwood; 2010.

Feder KL. Frauds, myths, and mysteries: science and pseudoscience in archaeology. 7th ed. Boston: McGraw-Hill; 2011.

Jordan P. The Atlantis syndrome. Stroud: Sutton; 2001.

Kusche L. The Bermuda Triangle mystery solved. Amherst: Prometheus; 1995.

Nickell J. Inquest on the Shroud of Turin. 2nd ed. Buffalo: Prometheus; 1987.

Plait P. Bad astronomy: misconceptions and misuses revealed, from astrology to the moon landing "hoax". New York: Wiley; 2002.

Powell EA. Theme park of the gods? Archaeology. 2004;57(1):62-7.

Radford B. Tracking the chupacabra: the vampire beast in fact, fiction, and folklore. Santa Fe: University of New Mexico Press; 2011.

Sabloff JA. Archaeology matters: action archaeology in the modern world. Walnut Creek: Left Coast Press; 2008.

Van Sertima I. They came before Columbus: the African presence in ancient America. New York: Random House; 1976.

von Däniken E. Chariots of the gods? New York: Bantam Books; 1970.

von Däniken E. The return of the gods: evidence of extraterrestrial visitations. New York: Element Books; 2000.

von Däniken E. The gods were astronauts: evidence of the true identities of the old gods. London: Vega Books; 2002. 